\title{
Urban life quality as an approach to sustainability: the case of Duzce city
}

\author{
E. Kutay Karacor \& P. Koylu \\ Department of Landscape Architecture, Duzce University, Turkey
}

\begin{abstract}
Cities have been becoming unhealthy since the industrial revolution due to dense immigration, environmental disruption, the increase of motor vehicles, insufficiencies in infrastructure etc., and have long lost their habitability. Along with the concepts of modernism and sustainability, different suggestions and approaches have been presented in order to increase the quality of life and solve the social problems within cities. Duzce city, our study area, is located in between two metropolitan cities - Istanbul and Ankara - and exhibits ecosystem richness, as well as biological diversity. However, as a result of the rapid urbanization after the disastrous earthquake in 1999, the structure of the society has changed and the natural environment has become subject to environmental degradation. Hence, this study aims to evaluate urban quality perception with reference to the socio-cultural differences of city inhabitants and develop suggestions for sustainable planning. Subjective indicators of physical environment, one of the components of urban life quality, have been considered as the main issue in determining the perception of urban quality. In this scope, oral interviews were conducted with 471 people from 48 neighborhoods. Stratified random sampling was used for the representation of each neighborhood due to its population. A physical environmental quality scale that was used for oral interviews consisted of 24 items, and seven factor groups were obtained in the factor analysis by using SPSS software. Relationships between factors and socio-demographic structure were tested by one way ANOVA and t-tests. As a result, by considering both the differences and expectations of all social groups living in Duzce, and the present conditions of the city, various planning and design solutions and suggestions have been developed for improving the sustainability of the city.

Keywords: urban life quality, physical environmental quality, Duzce city.
\end{abstract}




\section{Introduction}

Cities have been becoming unhealthy because of various reasons, such as rapid population growth, migration and industrialization, which also cause the emergence of various environmental problems. The term "sustainability" has been in use since the 1980s, and has been discussed along with the term "life quality" in several scientific studies. According to Moser [1] the definition of sustainability is related to satisfactory living conditions that help people identify themselves positively with their own environments. Hence, he refers to life quality by using "satisfactory living conditions" and builds a connection between life quality and sustainability.

Life quality studies are based on objective [2] or subjective [3] measurements and involve physical, social or economical dimensions [4] of various geographical areas. Especially, the subjective views of various actors regarding urban life quality are of great importance in terms of spatial planning since democratic participation is deemed as a requirement while making planning decisions. Thus, this study aims to draw attention to the importance of the consideration of the views of the actors involved in planning within the context of physical environmental quality (PEQ). Accordingly, in order to develop spatial recommendations, which will contribute to sustainability, opinions of different social groups living in Duzce city have been evaluated by subjective measurements of PEQ.

\section{Material and method}

\subsection{Material}

Duzce city, our study area, is located on the Black Sea coast of Turkey (Figure 1). It exhibits sea and forest ecosystems with great richness in biological diversity. Since the city is located in between two metropolitan cities - Ankara and Istanbul - its population increases due to migration from other cities. Hence, the physical environment is under the pressure of rapid changes. In addition, as a result of the great earthquake in 1999, the urban structure has undergone a rapid transformation and new neighborhoods have been developed along with social housing projects. The city consists of 48 neighborhoods and all of these neighborhoods are involved in this study.

\subsection{Method}

To determine the perception of PEQ of Duzce city, oral interviews were conducted with city administrators, citizens older than 15 years and experts who are involved in urban planning/design issues. A stratified sampling method has been used to ensure representation of all neighborhoods relative to the population size. 


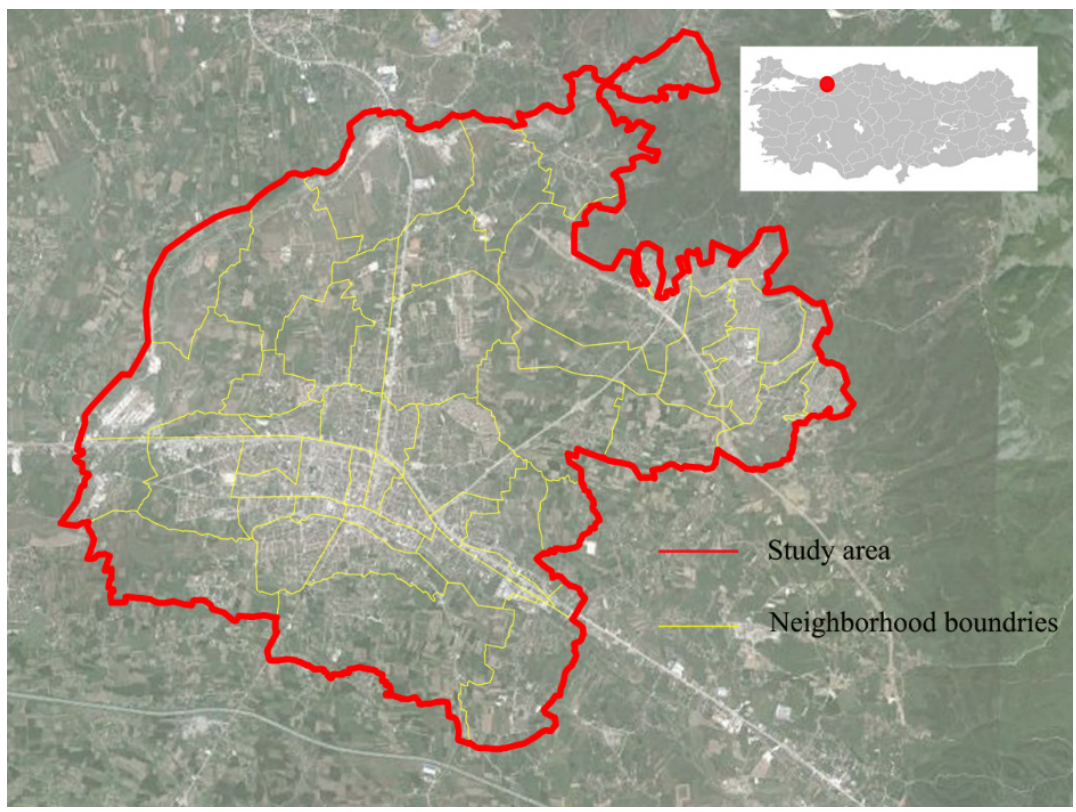

Figure 1: City center of Duzce.

There are different approaches in the literature with regard to acceptable sample size. While Winter et al. [5] recommend a sample size of less than 50 as acceptable, Mundfrom et al. [6] recommend a sample size of more than 200 for consistent factor recovery. On the other hand, Krejcie and Morgan [7] suggest that sample size depends on the population size.

Duzce city has a population of 129,118 . When individuals who are under the age of 15 are removed from the population size of the city, the new population size becomes 96,573. The sample size of the study, as shown in Table 1, has been determined by using the method that is suggested by Krejcie and Morgan [7].

Table 1: Population and sample sizes.

\begin{tabular}{llll}
\hline & Population Size & Min. Sample Size & $\begin{array}{l}\text { Number of Returned } \\
\text { Questionnaire }\end{array}$ \\
\hline City administrators & 104 & 83 & 52 \\
\hline Experts & 37 & 34 & 34 \\
\hline Citizens & 96456 & 383 & 384 \\
\hline Duzce City & 96573 & 500 & 470 \\
\hline
\end{tabular}

After the preliminary survey questions had been applied to 100 students from Duzce University, they were analyzed with SPSS 17 software and some items of the PEQ scale were redeveloped. Then, the questionnaire forms were distributed to the city administrators, experts and citizens. Although all of the questionnaires were returned from the experts and citizens, only 52 forms were returned from the city administrators. Thus, a total of 470 questionnaire forms have been evaluated. 
The questionnaire consisted of some socio-demographic variables, such as gender, age, education level, income level, occupation, household structure, and a PEQ scale. The PEQ scale in survey form was administered as a Likert-type scale, which provided survey participants with a choice from one to five, "1" representing strongly disagree and " 5 " representing strongly agree. The PEQ scale, as shown in Table 2, was composed of negative and positive items to increase the awareness of the participants. Negative items were reverse coded. The majority of these items were drawn from previous PEQ studies: EC [8]; Bonaiuto et al. [3]; Bonaiuto et al. [9], which have demonstrated good internal consistency or reliability.

Table 2: Physical environmental quality scale items.

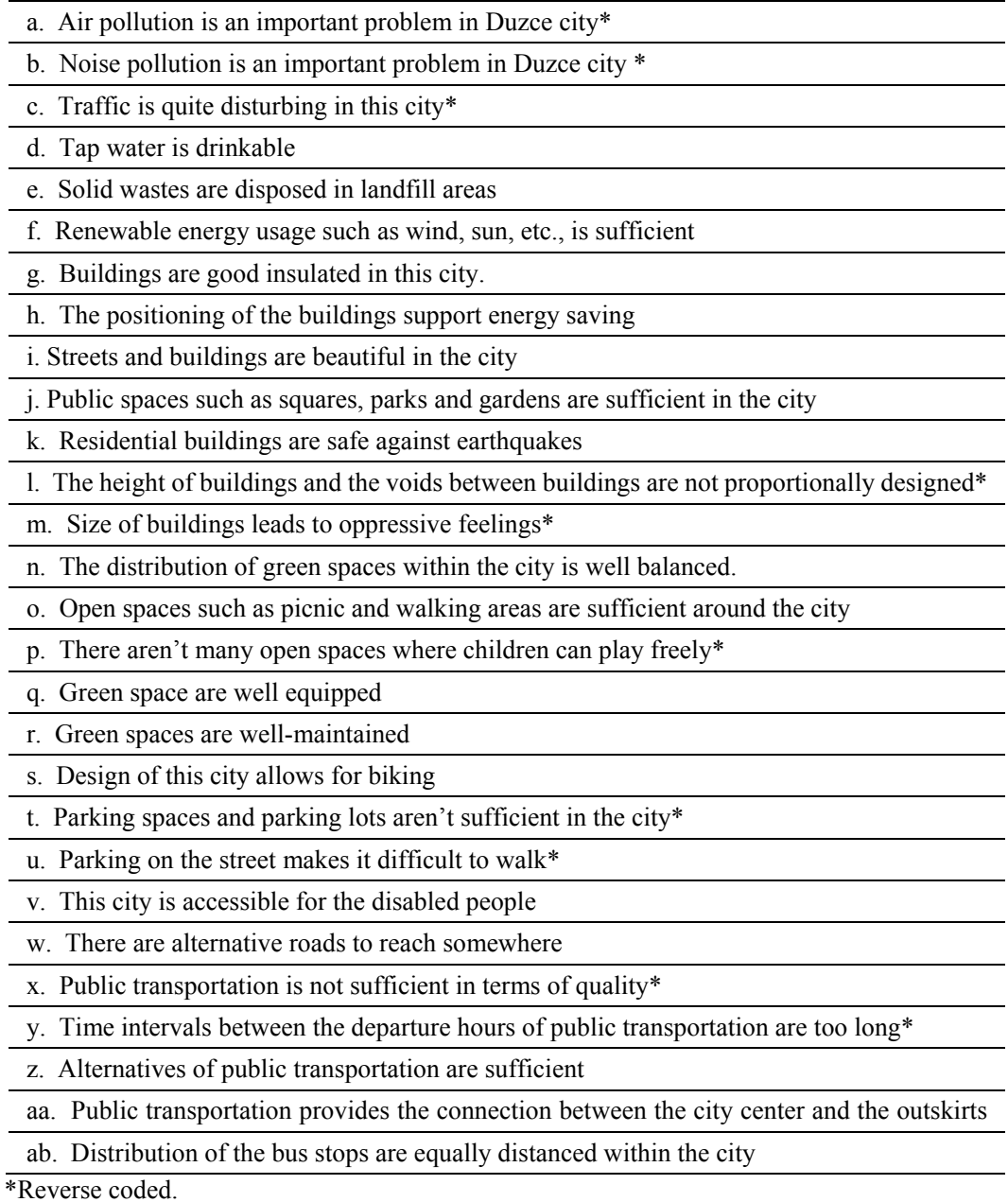




\section{Results}

An exploratory factor analysis was run on PEQ scale items for data reduction. According to Cokluk et al. [10], the analysis cannot be continued with a KeiserMeyer-Olkin value lower than 0.50 and, moreover, the factor loadings of each variable are required to be more than 0.32 in the exploratory factor analysis. Although the present study provided the requirements of literature with a K-M-O value of 0.81 , the factor loadings of some items were less than 0.32 . Hence, we excluded some items that had a factor loading less than 0.32 and were classified in more than one factor. Consequently, PEQ scale items were classified in 7 factor groups, and were labeled in accordance with the items comprising each group (Table 3).

Table 3: Physical environmental quality factor analyses.

\begin{tabular}{|c|c|c|c|c|c|c|c|c|}
\hline $\begin{array}{l}\text { Physical } \\
\text { Environmental } \\
\text { Quality }\end{array}$ & $\begin{array}{l}\text { Arithmetic } \\
\text { Mean of Each } \\
\text { Item }\end{array}$ & $\begin{array}{l}\text { PEQ } \\
\text { FI }\end{array}$ & $\begin{array}{l}\text { PEQ } \\
\text { FII }\end{array}$ & $\begin{array}{l}\text { PEQ } \\
\text { FIII }\end{array}$ & $\begin{array}{l}\text { PEQ } \\
\text { FIV }\end{array}$ & $\begin{array}{l}\text { PEQ } \\
\text { FV }\end{array}$ & $\begin{array}{l}\text { PEQ } \\
\text { FVI }\end{array}$ & $\begin{array}{l}\text { PEQ } \\
\text { FVII }\end{array}$ \\
\hline $\begin{array}{l}\mathrm{Fj} \\
\mathrm{Fn} \\
\mathrm{Fi} \\
\mathrm{Fo} \\
\mathrm{Fq} \\
\mathrm{Fk} \\
\mathrm{Fe} \\
\end{array}$ & $\begin{array}{l}2.44 \\
2.47 \\
2.72 \\
2.50 \\
2.55 \\
2.54 \\
2.88 \\
\end{array}$ & $\begin{array}{l}0.74 \\
0.71 \\
0.68 \\
0.61 \\
0.58 \\
0.56 \\
0.54 \\
\end{array}$ & & & & & & \\
\hline $\begin{array}{l}\text { Fh } \\
\text { Fg } \\
\text { Ff }\end{array}$ & $\begin{array}{l}2.18 \\
2.29 \\
2.27 \\
\end{array}$ & & $\begin{array}{l}0.79 \\
0.78 \\
0.71 \\
\end{array}$ & & & & & \\
\hline $\begin{array}{l}\mathrm{Ft} \\
\mathrm{Fu} \\
\mathrm{Fp} \\
\mathrm{Fl}\end{array}$ & $\begin{array}{l}2.37 \\
2.37 \\
2.85 \\
2.85\end{array}$ & & & $\begin{array}{l}0.76 \\
0.70 \\
0.51 \\
0.41\end{array}$ & & & & \\
\hline $\begin{array}{l}\mathrm{Fb} \\
\mathrm{Fa} \\
\mathrm{Fc} \\
\end{array}$ & $\begin{array}{l}2.59 \\
2.57 \\
2.54 \\
\end{array}$ & & & & $\begin{array}{l}0.83 \\
0.74 \\
0.68 \\
\end{array}$ & & & \\
\hline $\begin{array}{l}\text { Faa } \\
\text { Fab } \\
\text { Fz }\end{array}$ & $\begin{array}{l}2.92 \\
3.10 \\
2.65 \\
\end{array}$ & & & & & $\begin{array}{l}0.80 \\
0.71 \\
0.63 \\
\end{array}$ & & \\
\hline $\begin{array}{l}\text { Fv } \\
\text { Fs }\end{array}$ & $\begin{array}{l}2.66 \\
2.00\end{array}$ & & & & & & $\begin{array}{l}0.82 \\
0.71\end{array}$ & \\
\hline $\begin{array}{l}\text { Fx } \\
\text { Fy }\end{array}$ & $\begin{array}{l}2.80 \\
2.66 \\
\end{array}$ & & & & & & & $\begin{array}{l}0.82 \\
0.66 \\
\end{array}$ \\
\hline $\begin{array}{l}\text { Arithmetic Me } \\
\text { Alpha of Facto } \\
\text { Explained Var } \\
\text { Alpha of Scale } \\
\text { Total explaine } \\
\text { Keiser-Meyer- }\end{array}$ & $\begin{array}{l}\text { ce }(\%) \\
\text { ariance }(\%) \\
\text { sin }\end{array}$ & $\begin{array}{l}2.58 \\
0.81 \\
21.25 \\
0.81 \\
60.11 \\
0.81 \\
\end{array}$ & $\begin{array}{l}2.25 \\
0.74 \\
11.57\end{array}$ & $\begin{array}{l}2.61 \\
0.65 \\
6.84\end{array}$ & $\begin{array}{l}2.57 \\
0.70 \\
6.10\end{array}$ & $\begin{array}{l}2.89 \\
0.67 \\
5.29\end{array}$ & $\begin{array}{l}2.33 \\
0.56 \\
4.80\end{array}$ & $\begin{array}{l}2.73 \\
0.63 \\
4.23\end{array}$ \\
\hline
\end{tabular}

PEQ FI: Green spaces, buildings and urban layout; PEQ FII: Energy saving; PEQ FIII: Open spaces; PEQ FIV: Cleanliness; PEQ FV: Accessibility; PEQ FVI: Accessible transportation; PEQ FVII: Public transportation. 
The relationship between external nominal variables and factor groups of the PEQ scale were demonstrated by using one-way analysis of variance (one-way ANOVA) (Table 4).

Table 4: One way ANOVA of physical environmental quality.

\begin{tabular}{|c|c|c|c|c|c|c|c|c|}
\hline & & $\begin{array}{l}\text { PEQ } \\
\text { FI }\end{array}$ & $\begin{array}{l}\text { PEQ } \\
\text { FII } \\
\end{array}$ & $\begin{array}{l}\text { PEQ } \\
\text { FIII }\end{array}$ & $\begin{array}{l}\text { PEQ } \\
\text { FIV }\end{array}$ & $\begin{array}{l}\text { PEQ } \\
\text { FV }\end{array}$ & $\begin{array}{l}\text { PEQ } \\
\text { FVI } \\
\end{array}$ & $\begin{array}{l}\text { PEQ } \\
\text { FVII } \\
\end{array}$ \\
\hline \multirow[t]{5}{*}{ Planning actors } & A. Citizens & 2.62 & 2.67 & 2.67 & 2.59 & 2.88 & 2.35 & 2.73 \\
\hline & B. Administrators & 2.63 & 2.46 & 2.46 & 2.50 & 3.25 & 2.46 & 3.15 \\
\hline & C. Experts & 2.10 & 2.23 & 2.23 & 2.40 & 2.39 & 1.83 & 2.02 \\
\hline & $F$ & $6.44 * *$ & $5.51 * *$ & $4.44 *$ & 0.74 & $8.88 * * *$ & $5.73 * *$ & $10.07 * * *$ \\
\hline & Post Hoc & $\mathrm{A}, \mathrm{B}-\mathrm{C}$ & $\mathrm{A}-\mathrm{C}$ & A-C & & $\begin{array}{l}\mathrm{A}-\mathrm{C} \\
\mathrm{B}-\mathrm{A}, \mathrm{C}\end{array}$ & $\mathrm{A}, \mathrm{B}-\mathrm{C}$ & $\begin{array}{l}\mathrm{A}-\mathrm{C} \\
\mathrm{B}-\mathrm{A}, \mathrm{C}\end{array}$ \\
\hline \multirow[t]{4}{*}{ Gender } & A. Female & 2.54 & 2.19 & 2.60 & 2.61 & 2.76 & 2.28 & 2.66 \\
\hline & B. Male & 2.62 & 2.29 & 2.62 & 2.53 & 2.99 & 2.37 & 2.78 \\
\hline & $F$ & 1.29 & 1.39 & 0.10 & 0.78 & $6,76 * *$ & 1.19 & 1.30 \\
\hline & Post Hoc & & & & & B-A & & \\
\hline \multirow[t]{8}{*}{ Occupation } & A. Own businesses & 2.97 & 2.43 & 2.77 & 2.84 & 3.11 & 2.55 & 2.85 \\
\hline & $\begin{array}{l}\text { B. Own businesses and } \\
\text { employer }\end{array}$ & 2.73 & 2.42 & 2.55 & 2.58 & 3.04 & 2.47 & 2.78 \\
\hline & C. Part time & 2.54 & 2.78 & 3.03 & 2.45 & 2.85 & 2.52 & 2.85 \\
\hline & D. Worker/officer & 2.55 & 2.13 & 2.47 & 2.43 & 2.95 & 2.28 & 2.79 \\
\hline & E. Not employed & 2.47 & 2.18 & 2.64 & 2.60 & 2.72 & 2.20 & 2.57 \\
\hline & F. Other & 2.63 & 2.63 & 2.81 & 2.57 & 3.08 & 2.78 & 3.38 \\
\hline & $\bar{F}$ & $3.61 * *$ & $3.26^{* *}$ & 2.06 & 1.58 & $2.30^{*}$ & $2.72 *$ & 2.20 \\
\hline & Post Hoc & A-D,E & $\begin{array}{l}\text { All } \\
\text { groups }\end{array}$ & & & $\begin{array}{l}\text { All } \\
\text { groups }\end{array}$ & $\begin{array}{l}\text { All } \\
\text { groups }\end{array}$ & \\
\hline \multirow[t]{4}{*}{ Birth of place } & A. Duzce city & 2.64 & 2.27 & 2.65 & 2.58 & 2.97 & 2.32 & 2.78 \\
\hline & B. Outside of Duzce city & 2.50 & 2.22 & 2.55 & 2.57 & 2.75 & 2.35 & 2.65 \\
\hline & $\underline{F}$ & 2.98 & 0.29 & 1.26 & 0.01 & $6.08^{*}$ & 0.12 & 1.32 \\
\hline & Post Hoc & & & & & A-B & & \\
\hline \multirow{4}{*}{$\begin{array}{l}\text { Living in Duzce } \\
\text { city before } \\
\text { /after the } \\
\text { earthquake }\end{array}$} & $\begin{array}{l}\text { A. Living after the } \\
\text { earthquake }\end{array}$ & 2.46 & 2.22 & 2.54 & 2.52 & 2.74 & 2.30 & 2.52 \\
\hline & $\begin{array}{l}\text { B. Living before the } \\
\text { earthquake }\end{array}$ & 2.63 & 2.63 & 2.64 & 2.58 & 2.94 & 2.34 & 2.80 \\
\hline & $\bar{F}$ & 3.71 & 0.17 & 1.14 & 0.40 & $4.25^{*}$ & 0.15 & $5.35^{*}$ \\
\hline & Post Hoc & & & & & B-A & & B-A \\
\hline
\end{tabular}

${ }^{* p}<0.05 ; * * \mathrm{p}<0.01 ; * * \mathrm{p}<0.001$

According to this analysis, the perception of PEQ shows significant differences among groups. Administrators and citizens of Duzce city perceived green spaces, buildings and urban layout and accessible transportation as high in quality as compared to experts. Similar to these findings, we noticed that citizens of the city perceived energy saving, open spaces, accessibility and public transportation as highly acceptable as compared to experts. City administrators have accepted that accessibility and public transportation is high in quality as compared to citizens and experts (Table 4). 
When gender is considered, differences are observed only in terms of accessibility and males perceived the city more accessible as compared to females (Table 4).

In terms of occupation, green spaces, buildings and urban layout is perceived as higher quality by those who had their own businesses as compared to workers/officers and unemployed people. There are significant differences among all occupation states in the case of energy saving, accessibility and accessible transportation. Generally, the people are workers/officers and unemployed people perceived all factor groups as highly acceptable as compared other people (Table 4).

Place of birth shows differences only in terms of accessibility, hence those who were born in Duzce perceived accessibility as high in quality as compared to those who weren't.

Moreover, we considered differences between the people who have been living in Duzce city since before the 1999 earthquake and those who have immigrated after the earthquake and found that people who had been living in the city since before 1999 perceived accessibility and public transportation high in quality as compared to the others (Table 4).

Linear correlation analyses were run in order to compare the relationship between external ordinal variables and factor groups of PEQ (Table 5). According to correlation analysis, it has been found that green spaces, buildings and urban layout were positively related to age and length of residence in Duzce city, and negatively related to education level. Energy saving was positively related to the number of persons living together and negatively related to education level. Open spaces had a positive relationship with length of residence in the city and had a negative relationship with education and income levels. Cleanliness had a negative relationship only with education level. Accessibility was positively related to age, income level and length of residence in Duzce city. Accessible transportation had positive relationships with age and number of persons living together and had a negative relationship with education level. Public transportation was positively related to age and number of persons living together (Table 5).

Table 5: Linear correlation analysis.

\begin{tabular}{llllll}
\hline & Age & $\begin{array}{l}\text { Education } \\
\text { Level }\end{array}$ & $\begin{array}{l}\text { Income } \\
\text { Level }\end{array}$ & $\begin{array}{l}\text { Number of } \\
\text { Persons } \\
\text { Living } \\
\text { Together }\end{array}$ & $\begin{array}{l}\text { Length of } \\
\text { Residence in } \\
\text { Duzce }\end{array}$ \\
\hline PEQFI & $0.099^{*}$ & $-0.151^{* *}$ & 0.074 & 0.063 & $0.098^{*}$ \\
\hline PEQFII & -0.007 & $-0.183^{* *}$ & -0.031 & $0.115^{*}$ & 0.039 \\
\hline PEQFIII & 0.089 & $-0.203^{* *}$ & $-0.106^{*}$ & 0.068 & $0.103^{*}$ \\
\hline PEQFIV & 0.075 & $-0.164^{* *}$ & 0.039 & 0.017 & 0.031 \\
\hline PEQFV & $0.138^{* *}$ & -0.087 & $0.113^{*}$ & 0.068 & $0.121^{* *}$ \\
\hline PEQFVI & $0.095^{*}$ & $-0.118^{*}$ & 0.021 & $0.109^{*}$ & 0.042 \\
\hline PEQFVII & $0.111^{*}$ & -0.024 & 0.052 & $0.165^{* *}$ & 0.083 \\
\hline
\end{tabular}

$* \mathrm{p}<0.05 ; * * \mathrm{p}<0.01 ; * * * \mathrm{p}<0.001$. 


\section{Discussion}

According to Davidoff [11], encouragement of democratic urban government involves participation of the citizens in the planning process. As mentioned by Alfasi [12], some planners and theoreticians agree that, since planning lacks the integrated representation of different sectors of society, it cannot be considered as sufficiently democratic. Thus, we need to encourage both citizens and city administrators to take effective roles in urban planning and the design process in order to develop democratic solutions and equity. This would lead to the enhancement of social sustainability. There are several reasons for the differences of PEQ perception among the three groups (citizens, administrators, experts), which were described as actors in urban planning. While the citizens of Duzce city expressed deficiencies and their expectations according to their socio-cultural levels, administrators perceived urban services as sufficient since they were involved in providing them. The experts, as shown in Table 4, tended to be more objective and expressed deficiencies depending on theoretical and practical knowledge.

We found that males perceived Duzce city more accessible than females did (Table 4). According to Talen [13], perception of accessibility is changed according to some variables such as socio-economic structure, age and gender. In addition, Fadda and Jiron [14] drew attention, to the perceptual differences on urban life quality due to gender. However, Bonaiuto et al. [9] noticed that perception of physical environmental quality did not show any differences according to gender. On the other hand, Parks et al. [15] conducted a similar study on the neighborhood level, and they determined that quality perceptions of the males were lower than females.

Similar to our findings, which demonstrate positive relationships among 5 factors (perception of public transportation, accessibility, accessible transportation, green spaces, buildings and urban layout) and age, as shown in Table 5, the studies of Bonaiuto et al. [9] and Parks et al. [15] also reveal the existence of a positive relationship between perception of aesthetic value of buildings and age. Additionally, it was found that urban green spaces had positive effects on the perception of adolescents in some studies [16].

In this study, the perception of PEQ factors shows considerable differences according to education level. It was found that there is no relationship between education level and perception of accessibility and public transportation. However, a negative relationship was determined between other factor groups and the education level of the participants (Table 5).Thus, the study demonstrates that the higher the education level, the higher the environmental awareness and expectations of the people. Subsequently, as people become more aware of the shortcomings or deficiencies, and also have much more expectations, they perceive their environments as low quality.

Negative relationship between the perception of the quality of open spaces and income level, as shown in Table 5, could be due to the ownership of vehicles by the people having higher incomes. As they own cars, they might want to visit different types of open spaces. Pacione [17] expressed that people's income level 
was an important factor on the perception of physical environmental quality. The studies of Bonaiuto et al. [9] and Parks et al. [15] demonstrate positive relationships between income levels and the perception of pleasantness of buildings and green areas.

The result of this study reveal that workers/officers and unemployed people have lower levels of perceived quality (Table 4). The higher education levels of the workers/officers might be the cause of this result. On the other hand, as unemployed people have much more free time, they can observe the city better than the others, and hence, can perceive any shortcomings or deficiencies. Moreover, the majority of unemployed people are female and the perception of physical environmental quality of females was also found to be lower than males.

The number of persons living together has been found to have a positive relationship with energy saving, accessible transportation and public transportation (Table 5). The reason could be that large families have lower socioeconomic levels and consequently their expectations of these factors would be lower.

The participants who were born in Duzce perceived higher levels of quality as compared to those who were born out of Duzce (Table 4). This may be because people usually develop positive feelings towards places where they were born.

Similar to our findings, which demonstrate a positive relationship between length of residence and PEQ, as shown in Yable 5, Parks et al. [15] also suggest that perception of quality becomes higher as the length of residence increases. Thus, perception of accessibility and public transportation was seen as highly acceptable by those participants who had been living in the city before the 1999 earthquake, as shown in Table 4, and could be related to length of residence. Conversely, Bonaiuto et al. [9] found that quality of accessibility and public transportation was perceived as low quality by those who had been living in Rome for a longer time.

\section{Conclusion}

This study reveals that most of the urban services were perceived as high quality by the administrators as compared to the other actors involved in the planning process. This situation demonstrates the administrators' political concerns and subjective judgments when the quality of environment is in question. Therefore, other actors, other than the administrators should also participate in the planning process to develop planning policies which protect the rights of all the groups living within a city.

Considering the low quality of public transportation as perceived by the females, alternative public transportation services and the frequency of bus stops should be increased. Eventually, public transportation routes should also be rearranged to increase accessibility all around the city.

A need for open spaces was expressed especially by young people and the unemployed participants. Thus, public open spaces which would help the development of young people both physically and socially, as well as encourage the unemployed to participate in various activities should be designed 
within the city center. In other words, quality and quantity of open spaces should be increased. Besides, in order to ensure social equity, all urban services should be delivered to the outskirts of the city where low income groups live.

To increase energy saving of the city, citizens should be encouraged to use renewable energy resources. Accordingly, urban design policies should be developed and implemented by governors. Moreover, some considerations regarding urban design, such as planting windbreaks, locating buildings to create urban corridors, etc. could also help energy saving.

Newcomers to the city should be encouraged to establish ties with Duzce city. Thus, the physical structure of the city should be improved in order to create a more livable environment, which would also help the development of social sustainability within the city.

\section{References}

[1] Moser, G., Quality of life and sustainability: towards person-environment congruity. Journal of Environmental Psychology, 29(3), pp. 351-357, 2009.

[2] Marans, R.W., Understanding environmental quality through quality of life studies: the 2001 DAS and its use of subjective and objective indicators. Landscape and Urban Planning, 65(1-2), pp. 73-83, 2003.

[3] Bonaiuto, M., Fornara, F. \& Bonnes, M., Indexes of perceived residential environment quality and neighbourhood attachment in urban environments: a confirmation study on the city of Rome. Landscape and Urban Planning, 65(1-2), pp. 41-52, 2003.

[4] Ulengin, B., Ulengin, F. \& Guvenc, U., A multidimensional approach to urban quality of life: the case of Istanbul. European Journal of Operational Research, 130(2), pp. 361-374, 2001.

[5] Winter, J.C.F., Dodou, D. \& Wieringa, P.A., Exploratory factor analysis with small sample sizes. Multivariate Behavioral Research, 44(2), pp. 147$181,2009$.

[6] Mundfrom, D.J., Shaw, D.G. \& Ke, T.L., Minimum sample size recommendations for conducting factor analysis. International Journal of Testing, 5(2), pp. 159-168, 2005.

[7] Krejcie R.V., Morgan D.W., Determining sample size for research activities. Educational and Psychological Measurement, 30, pp. 607-610, 1970.

[8] European Commission (EC). The Urban Audit. Towards The Benchmarking of Quality of Life in 58 European Cities. Luxembourg: Office for Official Publications of the European Communities. ISBN 92828-9243-3, http://ec.europa.eu/regional_policy/archive/urban2/urban/audit/ftp/yearboo k/intro.pdf

[9] Bonaiuto, M., Aiello, A., Perugini, M., Bonnes, M. \& Ercolani A.P., Multidimensional perception of residential environment quality and neighbourhood attachment in the urban environment. Journal of Environmental Psychology, 19, pp. 331-352, 1999. 
[10] Cokluk, O., Sekercioglu, G. \& Buyukozturk, S., Sosyal Bilimler Icin Cok Degiskenli Istatistik - SPSS ve LISREL Uygulamalari. Pegem Akademi Yayınlari: Ankara, 2010.

[11] Davidoff, P., Advocacy and pluralism in planning. Journal of the American Institute of Planners, 31(4), pp. 331-338, 1965.

[12] Alfasi, N., 2003. Is public participation making urban planning more democratic? The Israeli experience. Planning Theory \& Practice, 4(2), pp. 185-202, 2003.

[13] Talen, E., Pedestrian access as a measure of urban quality. Planning Practice \& Research, 17(3), pp. 257-278, 2002.

[14] Fadda, G., Jiron, P., Quality of life and gender: a methodology for urban research, Environment and Urbanization, 11(2), pp. 1-13, 1999.

[15] Parks, A., Kearns, A., Atkinson, R., What makes people dissatisfied with their neighbourhoods? Urban Studies, 39(13), pp. 2413-2438, 2002.

[16] Makinen, K., Tyrvainen, L., Teenage experiences of public green spaces in suburban Helsinki. Urban Forestry \& Urban Greening, 7(4), pp. 277-289, 2008.

[17] Pacione, M., Urban environmental quality and human wellbeing - a social geographical perspective. Landscape and Urban Planning, 65(1-2), pp. 19-30, 2003. 